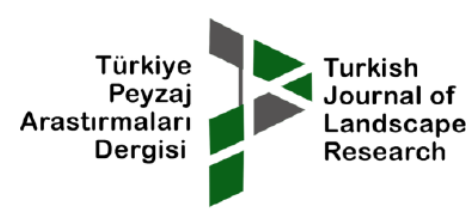

\title{
TRANSITION PROCESS OF LANDSCAPE THROUGH CHANGING TROPICAL GARDENS FROM PRODUCTIVE FUNCTION INTO RECREATIONAL PURPOSES
}

\author{
Rahman TAFAHOMi ${ }^{1 *}$ \\ ${ }^{1 *}$ University of Rwanda, College of Science and Technology, School of Architecture and Built Environment, Department \\ of Architecture, Kigali, Rwanda rtafahomi@ur.ac.rw ORCID:0000-0002-7172-1302
}

\begin{abstract}
The urban gardens are under transformation that results in the modification of function, activity, hardscape, softscape of gardens. The aim of this paper is to analyse the transitional process of the gardens from the productive function to recreational purposes in Kigali city, Rwanda. The methodology of the research was designed qualitative methods such as interview, observation, photography, sketching, mapping, and graphical analysis. The findings identified that the transition process has affected both the configuration and composition of gardens. The configuration refers to the hardscape including buildings, walls, paving, and accessibility, and composition includes the softscape such as trees, shrubs, flowers, pots, and furniture. Additionally, this transition resulted in changing functions and activities in the gardens from productive to leisure and from private to semi-private and semi-public. This transition could be addressed to the new generation of social middle classes in the city who are raising new needs, desires, and expectations from the urban area to increase social interaction through semi-public activities.
\end{abstract}

Keywords: Gardens, Hardscape, Softscape, configuration, Composition, Function 


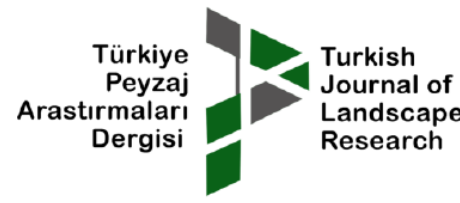

Türkiye Peyzaj Araştırmaları Dergisi

2021, 4:1, 45-63

Araştırma Makalesi

Turkish Journal of Landscape Research

2021, 4:1, 45-63

Research Article

\section{INTRODUCTION}

Nowadays, Kigali city as the capital of Rwanda is in the process of urbanization and development rapidly (OZ, 2007). The city area is under expanding and the city integrates villages, farms, and hills, gardens, and natural areas into the urban fabric under name of new development, redevelopment, and reconstruction. This development includes a significant effect on the surrounding forests, agroforestry, and gardens in the area (Noordwijk, et al., 2014) that is going to change the character of the gardens from the productive character such as agricultural, horticultural, and agroforestry into a new hardscape with buildings such as restaurants, wedding gardens, and bars that changes urban form (Crowder, 1993). Seemingly, a new style of architectural design, settlements (World Bank, 2012), and devillagization (Backeus, Lindberg, \& Stromquist, 2009) take the position in the city with a wide range of varieties of form, style, and footprint. For example, both reports of the typology of housing in Rwanda (World Bank, 2012) and the affordable housing (CoK, 2015) referred to the high density particularly the footprint of houses in the plot. However, those reports no referred to any case of mixture the housing with trees, gardens, or farms in the urban areas based on the missing evidence in the survey time. In this case, apparently, the green spaces are shrunk toward more constructed areas. Just governmental departments schools, hospitals or and a few public, semi-public, or semi-private plots include green spaces with courtyards, yards, or frontage. The masterplan of the city remarked on the wetlands and surrounding forests as issues to discuss and the inner gardens and farm of the city are dependent on a new detailed plan $(\mathrm{OZ}, 2007)$.

Nevertheless, the city includes rich background as an area in the forest context with agricultural and horticultural experiences. The last report of REMA (Rwanda Environment Management Authority) highlighted that $63 \%$ of the urban land occupied with kitchen gardens and urban farms (REMA, 2017) and urban policies support urban farming and gardening (MININFRA, 2015) despite the problem of the land fragment in the city (REMA, 2017). Nevertheless, the detailed district physical plan (CoK, 2013) just remarked the agroforestry in the macro-scale in the city without highlighting urban gardening (Newbury, 1992).

Seemingly, both configuration such as size and form of the land, and composition based on the species and trees in the city are under the transformation (REMA, 2017) to change the concept of the garden and the landscape forms in the area. Robinson (2004) in the study on the structure of gardens concluded that trees have been significant elements to create form and space by defining edge, centre, and corner to construct the meaning in terms of the architectural functions. Trees have been a major element in gardening due to size, shape, volume, and durability in the composition part (Paganová \& Jureková, 2012); however, studies of Baard and Kraaij (2014) emphasized a continuous process of increasing some alien trees such as Pinus, Acacia, and Eucalyptus to change the softscape in the African region. In the opposite point of view, studies remarked that emphasizing ecological planning and the native plants implied some ideological racialism than landscape (Hall, 2003). Therefore, despite a long debate on the native and nonnative plants, studies have shown a political, ideological, and nationalistic tendency than naturalistic and ecological (Groning \& WolschkeBulmahn, 2003).

Apparently, gardens have been under pressure of transforming form and species. This changing process has been permanent or temporary diverted; however; studies demonstrated that all changes resulted to modify both composition and configuration of the ecological landscape (Gökyer, 2013). Technically, the composition term refers to land coverage and the site layout in terms of softscape form of the landscape such as green, blue, and open spaces and the configuration term refers to the structure and connection in terms of hardscape such as buildings, roads, bridges, and infrastructure (Tafahomi \& Nadi, 2020; Tafahomi, 2021). For this reason, critical comments challenged the concepts of composition and configuration in detailed landscape studies in terms of microscale and recommended to the ecological studies through digital mapping in macroscale (Steckel, et al., 2014; Duflot, Ernoult, Aviron, Fahrig, \& Burel, 2017).

\subsection{Insight into the Gardens as a Manmade Element}

The history of gardens includes rich documentation and background in Europe, North America, Asia, and some part of Africa. The gardens have been analysed in the perspective of the development process of personalisation and conceptualisation the nature into manmade production due to the need and the pleasure in the study (Spirn, 1998). In this human intervention, the recreational and decorative elements performed as an important role to create scenery, pleasure, and relaxation in the construction of gardens (Bell, 2008; Moughtin \& Shirley, 2006) under influences of environment, climate, and culture (Shin, Chen, Lee, \& Kim, 2015). In this case, the concept 


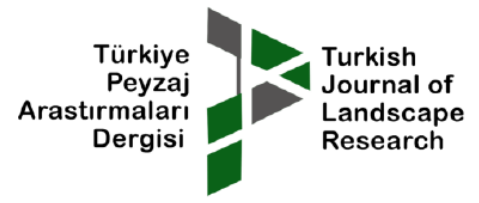

of the gardenscape proclaimed in terms of the specific cultural meaning in the relation to the time and location based on the inhabitant requirements and the desires (Alexsander, 1977; Spirn, 1998); however, simultaneously, there is a wide range of debates on the other political, ideological, economic, and social aspects of gardens (Helmreich, 2002).

In this debut, gardens have included considerable varieties of function, form, and character in the world (Wilkinson, 1994). The studies for example referred to some specifications such as the spiritual function of gardens in ancient Greece temples (Morris, 1979), decorative and leisure activities in the Roman style (Gleason, 2010), and amplification of houses (Groening \& Schneider, 1997). In addition, in Asia, studies referred to the echoes of paradise in the Persian garden (Khansari, Moghtader, \& Yavari, 2003), reflection the world in the small-scale with beauty and contrast in Chaises gardens (Keswick, Hardie, \& Jencks, 2003) or Zen in Japanese styles (Young, Young, \& Yew, 2011). However, in the Africa context, this background is limited to the Egypt precedents as nature and mythology (Wilkinson, 1994) and some new studies in South Africa with detailing of gardening in the colonial times (Bairnsfather, 2012), and finally, African-American gardens in United State experiences (Westmacott, 1992).

Studies also claimed that the leisure, productive, and decorative aspects have affected the changing of the forest into gardens. For example, the study identified that the original forest converted to a new function such as agroforestation, farm, or garden with different functions such as productive, decorative, leisure and entertainment, and other economic aspects (Noordwijk, et al., 2014). For this reason, Owusu argued that deforestation and agroforestation have been two common processes of designing gardens in the world (Owusu, 1993). Noordwijk reinterpreted that this process may be called by means of the linear process of changing forestry, to agroforestry, and then to agriculture, and consequently changing the general form of landscape in the global south (Noordwijk, et al., 2014).

In fact, the study has articulated that three factors have played a significant role in this transition of landscape including history, geography, and culture (Shin, Chen, Lee, \& Kim, 2015). Another study (Fu, Xiao, \& Wu, 2016) identified that stakeholders and the residents have had a significant role in the urban green transition in both positive and negative aspects. For this reason, Goldsmith addressed a common process of destroying the historic gardens in New Zealand with emphasizing as the common problem of the global south (Goldsmith, 2014). Seemingly, some essential elements of both hardscapes such as walls, paving network, and accessibility, and softscape particularly green spaces have been changed to facilitate the function for new purposes which, those called the configuration and composition (Gökyer, 2013) and hardscape and softscape (Tafahomi \& Nadi, 2020; Tafahomi, 2021) aspects in landscape design.

The studies in the definition of both landscape and garden highlighted that they have demonstrated manmade innovation (Spirn, 1998) something that differs from nature in various meanings and interpretation (Mugerauer, 2014). The meaning of gardens has referred to the other contextual parameters such as social, political, personal, spiritual, and national aspects. The studies have theorised that both the meaning and form of gardens have changed from a spiritual form into the functional and political forms in the whole of the history of the world (Pregill \& Volkman, 1999; Eyres, 2013). For example, the study of Jackson proclaimed that the landscape represents the political and cultural aspects of society more than an ecological concept (Jackson, 1979), in terms of unseparated part of the social and political condition in a specific period based on the ideology (Wolschke-Bulmahn \& Groening, 1992), and sense of patriotism based on the nationalism movement (Milam, 2017).

In the opposite viewpoint, Groening demonstrated that the garden represents the image and dream of the owner of the garden (Groening \& Schneider, 1997). In this regard, the interpretation of Tessin (Tessin, 1994) revealed that the meaning of the garden is so personal idea based on subjectivity than objectivities. Moreover, it was discussed that the meaning of landscape refers to the territorial demarcation features on the land and the cultural values and believes in different cultures (Bigell \& Chang, 2014). Seemingly, there is a tendency from beautification as the aesthetic achievement to the personal form as a variability in the gardening process (Groening \& Schneider, 1997), which created varieties of transformations.

For example, the study emphasised three general forms of gardens including the architectural gardens, agricultural plots as a manmade effort, and conserved natural areas (Micoulina, 2010). Another study has addressed to particular trend to express the landscape as the natural utopia (Groening, 2007) although looking for the naturalistic gardens and landscape no longer could be conceded as the issues of landscape topic with 


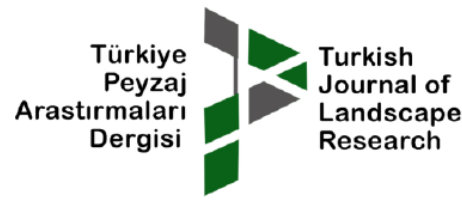

fading all forms of nature, and so garden and landscape have been in the changing position all the times (Groening, 2005). At this point, the study resented a classification for the gardens including formal-informal, peasant-aristocratic, and naturalistic-artistic due to the enlightenment and nationalism movements and based on the polarization in the nineteenth and twenty centuries although the formal gardens refer to the architectdesigned garden; however, the rural-gardens have been one style of designing in the countryside (Helmreich, 2002). The evidence reveals that the micro landscape idea was formed in the enlightenment times in Europe in which some concepts of the rural landscape were integrated into the city such as fruit landscape and courtyard garden (Groening \& Hennecke, 2014).

Furthermore, the social, cultural, and political trends have been the important reasons for changing gardens. For example, Hermand (1997) revealed that the new movement of garden designing has been under influences three factors particularly "middle-class enhancement, political relations with other countries, enlightenment movement, and marginalizing of bourgeoisies" power in Europe particularly England and France in eighteen and nineteen centuries. Additionally, Schenker argued that the rationalisation and industrialisation movement introduced a de-naturalistic approach in garden designing (Schenker, 2013) to be more productive and decorative than contextual. In addition, the studies about the transition of the landscape in the global south have addressed the urbanisation, industrialisation, and mechanisation processes as the most effective factor to change the form and scale of the landscape (Swaffield \& Primdahl, 2006; Antrop \& Eetvelde, 2008; Antrop M. , 2013).

Nevertheless, the garden story was different in the Africa context. Studies of Owusu (1993, pp. 317-19) revealed that the traditional and aboriginal agriculture and horticulture were destroyed in the colonising time based on the preference and policy for "export of productions, priorities to develop the urban areas, the bureaucratisation of the production, and changing of production management from women to men". In detail, the main ecological problem of African countries in the colonisation and after that time has been in three main categories such as "endangered, deforestation, and desertification" (Mazrui, 1993, p. 910). In this process, landscape features and elements were colonised to distribute language, culture, and ideas in the new locations (Bowring, 2014). There have been trends in the social and economic values to affect landscape and forestry (Buyinza, 2004). Therefore, the cultural values as a protector of biodiversity were decreased gradually in Africa (Munyaneza, Bizuro, Nshutiyayesu, Bigendako, \& Minani, 2009).

In an opposite view, studies on the history of Belgium colonisation style identified that the colonialist kept the system of local chief management among peasants particularly in Rwanda and Burundi; hence, the style was more traditional in the area (Crowder, 1993). Therefore, the transition process of the natural environment more was adapted to the agroforestation, deforestation, cultivation than garden designing based on the nonproductive aspects in the country. It seems the landscape studies have been explained in the region as three major concepts of analysis including, chronological, ecological, and morphological (Bashir, 2007) trends with different purposes and intentions. Recently, the studies by Tafahomi and Nadi (2020) and Tafahomi (2021) revealed that the green spaces followed an ad hoc approach for landscape design in the area and important projects like hospitals and schools did not follow a systematic process of design for landscape and gardens. Therefore, despite the rich green spaces background in the region, the structure of the landscape design, maintenance, and development less followed a landscape knowledge. Therefore, the hardscape and softscape of the landscape presented an eclectic style than the purposed base design.

In summary, gardens in term of the constructed landscape have been included some aspects of hardscape, softscape, function and activity, and meaning as Table one summarizes the topics. The applied hardscape and softscape elements demonstrate the trends of changing the gardens in the areas. Despite the contradictive ideas on the traditional form of gardens in the context of Africa, the available gardens in the context probably could demonstrate the specification of gardens with respect to the time and location. However, the current study emphasizes that the landscape concept is going to change in the changing world (O'Donoghue, SandovalRivera, \& Payyappallimana, 2019). 


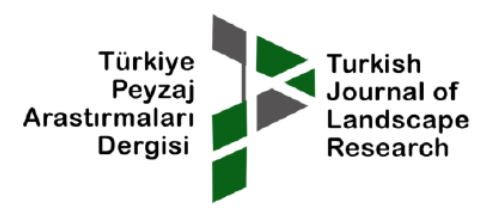

Table 1. Summary of the literatures

\begin{tabular}{|c|c|c|c|}
\hline Author & Form & Functions & Refer to \\
\hline (Morris, 1979) & (unspecified) & Spiritual & Greece Garden \\
\hline $\begin{array}{l}\text { (Wolschke-Bulmahn } \\
\text { \& Groening, 1992) }\end{array}$ & (unspecified) & $\begin{array}{l}\text { Political, ideological, } \\
\text { economic, and social }\end{array}$ & Ideology and patriotism \\
\hline $\begin{array}{ll}\text { (Mazrui, } & 1993) \\
\text { (Owusu, 1993) }\end{array}$ & $\begin{array}{l}\text { Destruction of natural form in } \\
\text { Africa }\end{array}$ & Garden & Colonization, export of production \\
\hline (Crowder, 1993) & Traditional form in Rwanda & Garden & the system of local chief management \\
\hline (Tessin, 1994) & General Form & Garden & Subjectivity \\
\hline (Wilkinson, 1994) & Natural form & Garden & Mythology \\
\hline $\begin{array}{ll}\text { (Groening } & \& \\
\text { Schneider, 1997) }\end{array}$ & $\begin{array}{l}\text { beautification as an aesthetic } \\
\text { form }\end{array}$ & Variety & $\begin{array}{l}\text { image and dream of the owner of the garden as } \\
\text { a personal form }\end{array}$ \\
\hline (Hermand, 1997) & $\begin{array}{lll}\begin{array}{l}\text { European } \\
\text { eighteen } \\
\text { centuries }\end{array} & \begin{array}{c}\text { garden } \\
\text { and }\end{array} & \begin{array}{l}\text { in the } \\
\text { nineteen }\end{array} \\
\end{array}$ & garden & $\begin{array}{l}\text { middle-class enhancement, political relations } \\
\text { with other countries, enlightenment } \\
\text { movement, and marginalizing of bourgeoisies }\end{array}$ \\
\hline (Spirn, 1998) & Unnatural & $\begin{array}{l}\text { Productive } \\
\text { pleasure }\end{array}$ & Personalization of nature based on innovation \\
\hline (Helmreich, 2002) & $\begin{array}{l}\text { formal-informal peasant- } \\
\text { aristocratic naturalistic-artistic }\end{array}$ & Garden & $\begin{array}{l}\text { enlightenment and nationalism movements, } \\
\text { Architect designed }\end{array}$ \\
\hline $\begin{array}{l}\text { (Keswick, Hardie, \& } \\
\text { Jencks, 2003) }\end{array}$ & (unspecified) & Beatification & Decoration \\
\hline $\begin{array}{l}\text { (Moughtin \& Shirley, } \\
\text { 2006) }\end{array}$ & Variety & Relaxation & Natural connection \\
\hline (Groening, 2007) & landscape as the natural utopia & Garden & Ideal image \\
\hline $\begin{array}{l}\text { (Bell, } \begin{array}{c}\text { Design for } \\
\text { outdoor } \\
\text { 2008) }\end{array} \text { recreation, } \\
\end{array}$ & Scenery & Pleasure & Visual quality \\
\hline (Gleason, 2010) & (unspecified) & Decorative, leisure & \\
\hline (Micoulina, 2010) & $\begin{array}{llr}\text { architectural } & \text { gardens, an } \\
\text { agricultural plots as a } \\
\text { manmade } & \text { effort, } & \text { and } \\
\text { conserved natural areas } & \\
\end{array}$ & Garden & Process of changing \\
\hline $\begin{array}{l}\text { (Young, Young, \& } \\
\text { Yew, 2011) }\end{array}$ & Central courtyard & Zen & Personal perception \\
\hline (Gökyer, 2013) & $\begin{array}{l}\text { Composition and } \\
\text { configuration }\end{array}$ & Landscape design & Proportion \\
\hline (Schenker, 2013) & $\begin{array}{l}\text { de-naturalistic approach in the } \\
\text { garden designing }\end{array}$ & garden & $\begin{array}{lll}\begin{array}{l}\text { rationalization } \\
\text { movement }\end{array} & \text { and industrialization } \\
\end{array}$ \\
\hline $\begin{array}{l}\text { (Noordwijk, et al., } \\
\text { 2014) }\end{array}$ & (unspecified) & $\begin{array}{l}\text { Forestry, } \\
\text { agroforestation, } \\
\text { agriculture and farm, } \\
\text { or garden }\end{array}$ & deforestation and agroforestation \\
\hline $\begin{array}{ll}\text { (Groening } & \& \\
\text { Hennecke, 2014) } & \\
\end{array}$ & Rural Landscape & Fruit Garden & Countryside pattern \\
\hline (Bowring, 2014) & $\begin{array}{l}\text { Colonization of landscape } \\
\text { form }\end{array}$ & Garden & To express new language, culture, and ideas \\
\hline $\begin{array}{l}\text { (Shin, Chen, Lee, \& } \\
\text { Kim, 2015) }\end{array}$ & $\begin{array}{l}\text { Adapted with the climate and } \\
\text { culture }\end{array}$ & Garden & Contextual \\
\hline $\begin{array}{l}\text { Tafahomi \& Nadi } \\
\text { (2020) }\end{array}$ & Natural from of gardens & $\begin{array}{l}\text { Therapeutic } \\
\text { Landscape and } \\
\text { Healing gardens }\end{array}$ & Therapeutic landscape for hospitals \\
\hline Tafahomi (2021) & $\begin{array}{l}\text { Integrated landscape with } \\
\text { gardens }\end{array}$ & $\begin{array}{l}\text { Recreational and } \\
\text { eatable }\end{array}$ & Landscape for the pupils in primary schools \\
\hline
\end{tabular}

\section{METHODS AND MATERIALS}

This part explained the methodology, research design, research process, data specification, and time and location of the research.

\subsection{Methodology}

The methodology of studies in the garden, landscape, and green spaces was included both quantitative and quantitative methods. The quantitative method was applied for large scape analysis particularly ecological studies with application of pattern analysis, spatial analysis, and spatial modelling (Turner \& Gardner, 1994; 


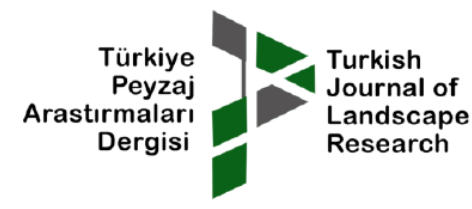

Turner, 2015) that were mentioned in terms of macroscale for green space and land coverage studies (Steckel, et al., 2014; Duflot, Ernoult, Aviron, Fahrig, \& Burel, 2017). The methodological studies also recommended correlation studies between phenomena in the studies such as water and soil based on the quantitative data (Deming \& Swaffield, 2011). However, the qualitative method was applied to study the landscape elements in the context of the study (Groat \& Wang, 2002; Deming \& Swaffield, 2011; Niezabitowska, 2018) with emphasizing the quality of the data. This method applied for focusing on the deep understanding of facts (Silverman, 2004) to evaluate both current conditions and transformed gardens with the descriptive and interpretative approaches (Deming \& Swaffield, 2011; Mugerauer, 2014; Krippendorff, 2003).

The studies applied qualitative research with a wide range of techniques such as the historic analysis (Groat \& Wang, 2002), storytelling (Given, 2008; Koskinen, Zimmerman, Binder, Redstrom, \& Wensveen, 2011; Denzin \& Lincoln, 2018), structured observation (Bonnes \& Bonaiuto, 2002; Tafahomi \& Nadi, 2020), site analysis (Moughtin \& Shirley, 2006; Baard \& Kraaij, 2014), graphical analysis (Antrop M. , 2013; Tafahomi \& Nadi, 2020; Tafahomi, 2021), photography (Sampson \& Gifford, 2010; Georgoula, Stamnas, Patias, Georgiadis, \& Fragkoulidou, 2013; Tafahomi \& Nadi, 2016), and sketching (Laseau, 2000; Trancik, 1986; Regis, 2003; Sperlregen, 2003; Tafahomi \& Nadi, 2020). For example, the study recently evaluated the current condition of the landscape in the psychological hospitals in the city with emphasizing on the qualitative method through the interview, structured observation, sketching, mapping, and graphical analysis (Tafahomi \& Nadi, 2020). Another study analysed the quality of the landscape in the primary school through the graphical technique to highlight the quality of the hardscape and softscape and effect on the users (Tafahomi, 2021).

\subsection{Research Design}

This research was designed based on the qualitative method (Mugerauer, 1995; Silverman, Doing qualitative research, 2010; Neuman, 2006) with the objective to analyse the data in the real context (Groat \& Wang, 2002; Niezabitowska, 2018). The applied techniques in the research were included in the structured observation to discover the hardscape and softscape in the gardens such as studies (Tafahomi \& Nadi, 2020), photography to record key factors in the gardens (Sampson \& Gifford, 2010; Georgoula, Stamnas, Patias, Georgiadis, \& Fragkoulidou, 2013; Tafahomi \& Nadi, 2016), sketching (Laseau, 2000; Regis, 2003; Sperlregen, 2003; Tafahomi \& Nadi, 2016; Tafahomi, 2021) to illustrate the structure of the gardens. Other techniques were applied to analyse data such as site analysis to overlay data (Groat \& Wang, 2002; Moughtin \& Shirley, 2006; Tafahomi, 2021), interview with elder people to find out the location and information for the gardens through the snowball technique (Neuman, 2006; Marshall \& Rossman, 2006), and graphical analysis to transfer data into analytical illustration (Laseau, 2000; Trancik, 1986; Regis, 2003; Sperlregen, 2003; Tafahomi \& Nadi, 2020; Tafahomi, 2021). Figure 1 represents the research design of the research. 

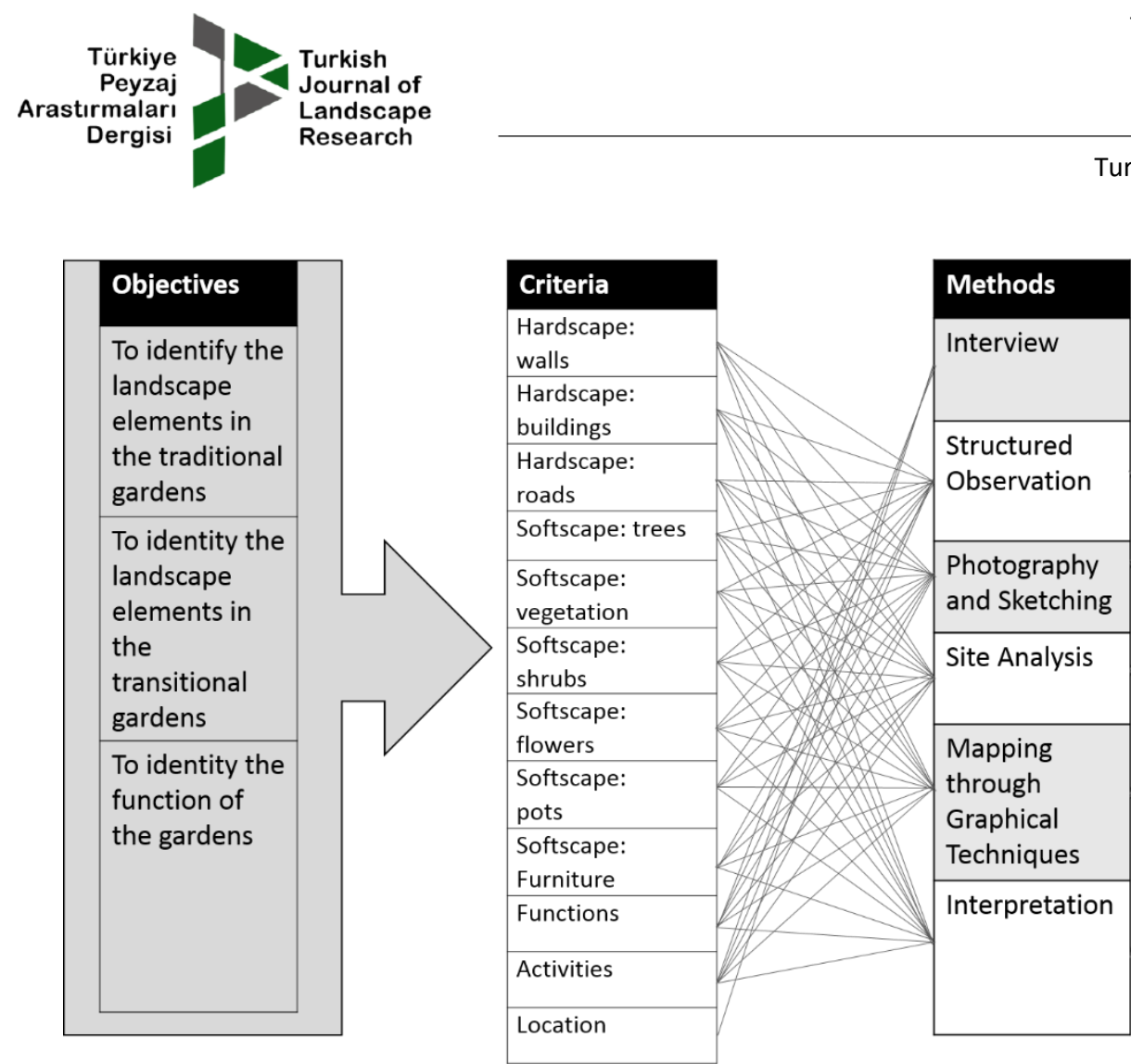

Research Article

Figure 1. Research design of the study

\subsection{Research Process}

Data were collected in two important stages in the research process. First, locations of the old gardens were identified through a depth interviewing with elder's people to track addresses whatever contextual gardens in the city based on the snowball technique (Miller, Dingwall, \& Morphy, 2004; Marshall \& Rossman, 2006). To discover essential data for the research, the research team attempted to identify an informative person and for the interview to ask the location of a traditional or old garden for visiting and documenting in each urban cell. The questions were simple questions including whether they could know any traditional or old garden to introduce. Where does it locate? In addition, whether are other people that they could introduce for an interview in terms of an informative person?

Second, those addresses were visited to confirm the existing of the gardens in the proper condition. The garden must be included active and at least with some of the green space elements such as trees, shrubs, and vegetation. If the garden was active, the physical features recorded and mapped in the survey based on the hardscape and softscape data (APA, 2006; Tafahomi \& Nadi, 2020) otherwise, the garden was removed from the list of the potential garden for analysis. It was clarified that some of those gardens no longer exist, some of them changed, transformed, and some of them were just farms. Therefore, among 37 addresses, just sixteen gardens were included minimum criteria based on the proportion of green space, open space, and productive-leisure character in different visiting (Bell, 2004; Groat \& Wang, 2002; REMA, 2017). They included either historical, natural, physical elements as a traditional garden or the functions and activities as a transformed garden.

\subsection{Data Specifications}

To construct a unique format for the analysis, some semi-geometric forms of the land converted into a basic form of the square to enable comparing of the structure and landscape elements and features as the process of mapping (White, 1983; Paganová \& Jureková, 2012; Gökyer, 2013; Laseau, 2000; Tafahomi, 2021). For this reason, iconic symbols were designed based on the hardscape particularly houses, buildings, and other constructions, and softscape included trees, flowers, vegetation, and decorative elements. All physical features converted into graphical symbols to illustrate spatial structure and relationships between landscape elements (White, 1983; Laseau, 2000; Tafahomi, 2021). Key criteria for the analysis were included three main components including 1) the site structure, site layout, and mass and spaces, 2) the site green spaces arrangement including trees, vegetation, flowers, and grass coverages, and 3) the site function such as productive, recreational, institutional and so on. In the analysis process, the main objective of the analysis was to discover significant elements in all instances of the research. 


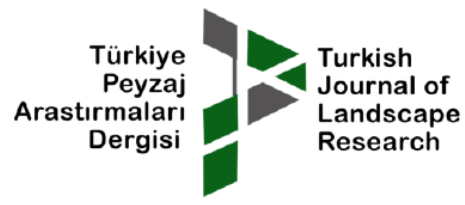

Despite the shape of gardens included a wide range of size, slope, and form, but those entire samples were so close to the rectangular shape due to two main elements constructed this shape. First, contour lines of topography formed the lengths side of the lands based on the two latitudinal lines. Second, the runoff traces on the land in the rainy seasons formed the longitudinal lines in the slopes of those contour lines as the widths of plots. Therefore, the conceptual latitude and longitude lines formed rectangular shapes with gentle corrugations in which were supported and enforced by trees, shrubs, and other elements to fix, address, and highlight as the cornerstones of the boundaries of gardens as Table 2. Hence, it normally could be observed varieties of shapes between those contour lines such as rectangles, squares, trapezoid, and parallelograms.

Table 2. Example of the forms of Gardens and Plots in the city and Surrounding areas

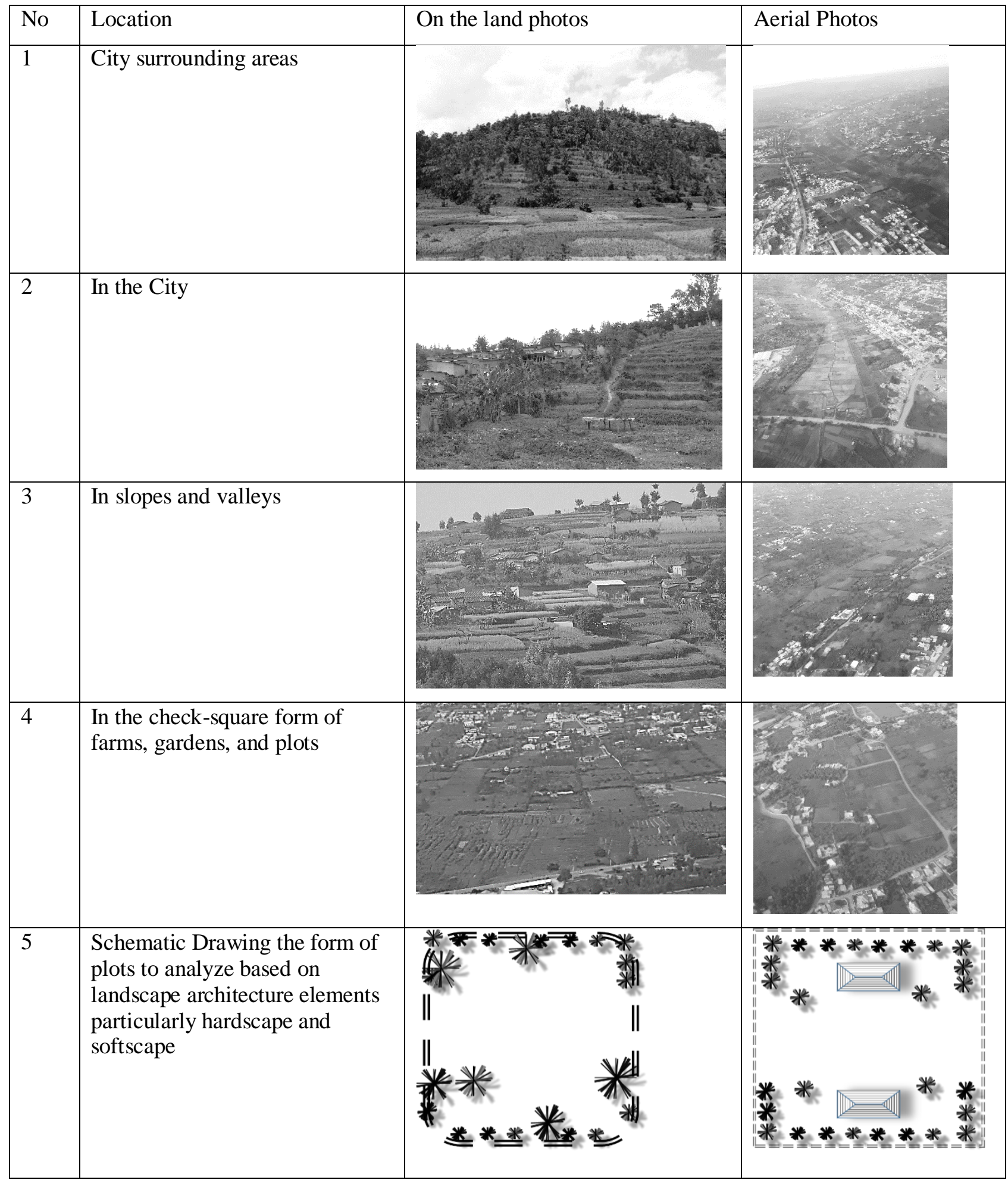




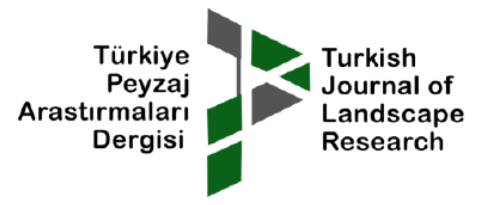

To harmonize the structure of the analysis three specifications were selected as the benchmark of analysis including the hardscape as the form, softscape as the structure of the green spaces, and the main function of the garden. The hardscape included hardscape such as houses, boundary, the void, reference point, and paving networks, those formed the hardscape part of the garden. The softscape included softscape such as trees, vegetation, flowers, and decorative elements. The function defined as the main possibility or purpose of the plot could serve human need. This function included a range of typology between public-private activities in the garden as a house, office, restaurant, or other activities. Data converted into graphic standards for the landscape design, analysis, and evaluation (Harris \& Dines, 1998; Hopper, 2007).

\subsection{Limitation and Implication}

This research did not use quantitative data and methods to evaluate and measure the green spaces and the numbers of the specific trees, vegetables, shrubs, flowers, and decorative elements in the gardens. Perhaps such quantitative data could open a new perspective for the research that was missed. In addition, the number of users and production of the gardens did not estimate and was not part of the scope of the research that certainly adding information could be useful for the specific users.

Despite data were collected based on the high level of precision, the research did not cover all of the gardens in the city due to the limitation of the accessibility and agreements of the owners for the site visiting and data collection. Therefore, the possibility to visit all the gardens and the sample in the city could perhaps include some effects on the results and trends in the research that prediction of the level of effects was not possible.

\subsection{Time and Location}

The study took place in Kigali as the capital of Rwanda. The city is located in a tropical climate with the background as a forest at $1^{\circ} 57^{\prime} \mathrm{S} 30^{\circ} 4^{\prime} \mathrm{E}$. This transformation all occurred in one century so; the speed of change was so high. The city included a 1.22 million population, inhabitants, and professions such as agriculture (24\%), industry (21\%), and trade activities (20\%), others (36\%). The city also has been faced a high level of immigration from rural areas due to urbanization policies. The green spaces, farms, and forest areas took the position in the urban area with almost 67\% (REMA, 2017) and surrounding areas of the city (OZ, 2007). Despite the recommendation of the master plan to integrate living areas with green spaces, however, implementation policies or guidelines were missing in the document. Data collected through teamwork with the landscape students between September and December in 2018. Figure 2 represents the location of the study.

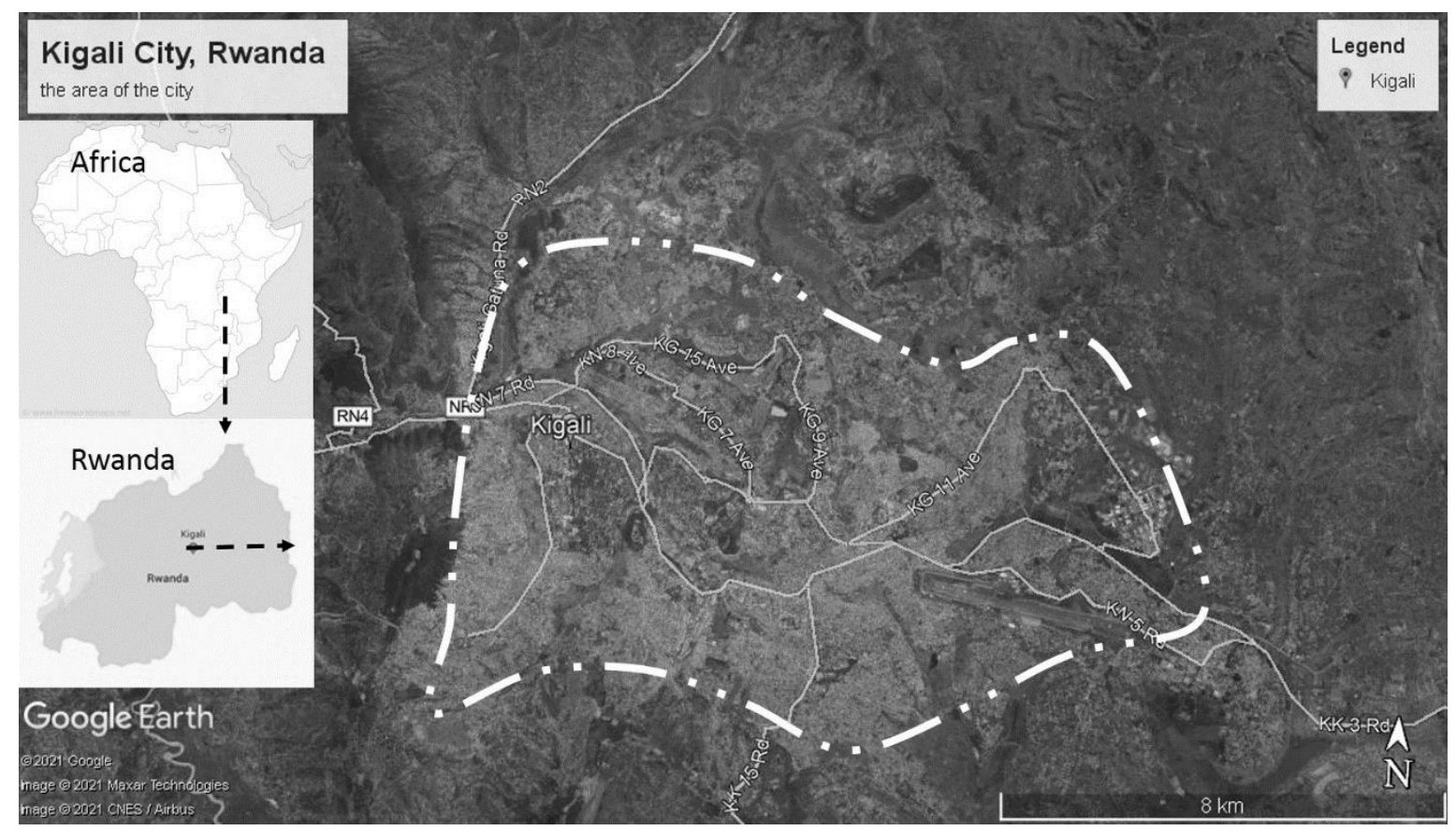

Figure 2. the area of the study 


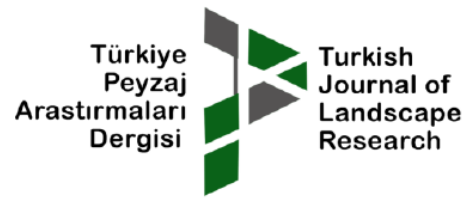

\section{RESULTS}

Research Article

All gardens analysed based on the layout of information and graphical analysis and result of the analysis as the explanation in tables 3 and 4 .

Traditional Gardens: traditional gardens were included in three categories comprising the gardens integrated with the buildings, the garden with the farming activity, and the gardens as a leftover part of the forest. First, in the gardens integrated with a building, the building took the position in the corner of the land as a reference point to define the area for better monitoring and managing of the plot. Therefore, the form of the garden defined as an integrated part of the softscape in the plot to serve the hardscape structure as a most permanent element. This building normally took the position in the most height part of the land for visibility and protection of runoff in the rainy seasons. The frontage of the building encompassed a void space and the surrounding areas were covered by green spaces. Second, the gardens with a farming area were comprised of verities of forms in the integration with agricultural and horticultural activities based on the topography and the form of the land similar to activities in villages in terms of productive-wood trees and vegetables such as root, seed, and flower. Third, the garden in the form of a leftover of the land or forest, normally they were surrounded with some wood trees for more protection than gardening. The schematic form of the traditional gardens compared in Table 3.

The attribute of the traditional gardens included four specifications. Firstly, the gardens areas unseparated from farming areas with both geometric and non-geometric forms. Secondly, some fruitful trees planted in the place as a reference point to separate the garden from other farms or ownership specifically mango, avocado, and banana. Thirdly, the forest trees also conserved as an edge of the plot to define the territories, surrounding areas, and to occupy the land or plot majority with some Grevillea, Pine, and Yucca trees. Fourthly, the interior paths with the paving structure were not constructed, observed, or detected in the examples and just different accesses from the outside roads were provided.

Transformed Gardens: the data highlighted seven important specifications in the transformed gardens. First, a geometric structure: the geometric structure emerged through a rectangular form of the plot based on the land subdivision pattern due to the contour lines also the features in the boundary of the plot such as walls, fences, and trees. Second: the building as the predominated element: the buildings were important manmade elements in the transformed gardens to define the structure such as linear, cluster, and surrounded forms based on the indoor-outdoor activities. In some of those samples, the building was the main element of the structure of the garden to arrange the central courtyard and the green spaces in the surroundings. Third, applying flowers and vases to define spaces: flowers, decorative shrubs, flowerpots, and furniture were applied in the transformed gardens to define the space, subspaces, beauty, and a place for hangout. Those elements were used to complete the main forms of the plot and develop it into a recreational attribute for more enjoyment than production. Fourth, integration of trees with the plot: a mixture of the fruit, forest, and decorative trees were observed in the transformed gardens, however, those fruit and decorative trees took the position in the central part of the gardens than in the edges as hedges. According to the samples, the trees were included a wide range of ages that could refer to a new plan for the planting in the plots to increase the level of the variety. Fifth, a void in the central space: all transformed gardens implied emphasising on the central part of the plot to delineate a void form of space in term of a key element in the structure of the garden through the arraying of open space in the middle. Sixth, applying linear structure: the liner structure was the major form in the transformed gardens. Despite the orthogonal form of some of the precedents with the iteration of the linear form, the linear form was the major character of those gardens to shape a connection of all parts of the plot together. Seventh, roads as the main element of the structure: the paving roads connected all part of the gardens together based on the linear form of the structure. Indeed, the paving, road network, and accessibility created a circulation opportunity for users to access the plot. Tables 3 and 4 summarise, illustrate, and represent all information for comparison. 


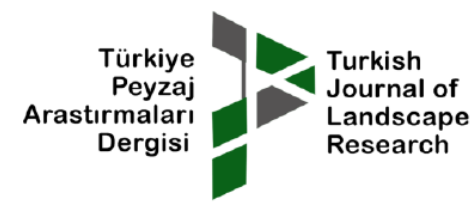

Table 3. Analytical table for the Traditional Gardens

\begin{tabular}{|c|c|c|c|c|}
\hline No & $\begin{array}{l}\text { Location and } \\
\text { Activity }\end{array}$ & $\begin{array}{l}\text { Layout of the } \\
\text { Gardens }\end{array}$ & $\begin{array}{l}\text { Graphical } \\
\text { Analysis of the } \\
\text { Structure }\end{array}$ & Explanation \\
\hline 1 & $\begin{array}{l}\text { A: } \\
\text { Garden with } \\
\text { farming } \\
\text { activates }\end{array}$ & 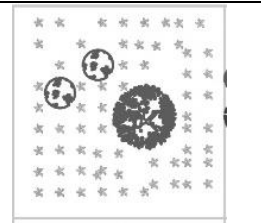 & & $\begin{array}{l}\text { Hardscape: the trees as a reference point in centre and greenery } \\
\text { in the surrounding as the territories } \\
\text { Softscape: avocado and guava trees in centre and beans } \\
\text { vegetable in surrounding } \\
\text { Function: a productive and private area } \\
\text { Activities: framing, production }\end{array}$ \\
\hline 2 & $\begin{array}{l}\text { B: } \\
\text { Garden with } \\
\text { building }\end{array}$ & & & $\begin{array}{l}\text { Hardscape: the buildings located in an open area and the } \\
\text { opposite side a mass of garden trees. } \\
\text { Softscape: the vegetable and gardening were divided by mass of } \\
\text { Grevillea and Banana trees } \\
\text { Function: education and hostel } \\
\text { Activities: private users }\end{array}$ \\
\hline 3 & $\begin{array}{l}\mathrm{C}: \\
\text { Garden as } \\
\text { reminded part } \\
\text { of a forest }\end{array}$ & & & $\begin{array}{l}\text { Hardscape: garden as leftover part with forest trees to create a } \\
\text { boundary with a central void } \\
\text { Softscape: forest trees such as Grevillea and Pine with natural } \\
\text { lawns in centre } \\
\text { Function: private, reserved area } \\
\text { Activities: conservation of the land }\end{array}$ \\
\hline 4 & $\begin{array}{l}\text { D: } \\
\text { Garden as } \\
\text { reminded part } \\
\text { of a forest }\end{array}$ & & $\begin{array}{l}-1 \times 1 \\
-1<-8\end{array}$ & $\begin{array}{l}\text { Hardscape: garden as a leftover part with forest trees to occupy } \\
\text { land } \\
\text { Softscape: apply the trees with Grevillea and Pine in the gridding } \\
\text { structure. } \\
\text { Function: public, as a forest resource } \\
\text { Activities: conserved area }\end{array}$ \\
\hline 5 & $\begin{array}{l}\text { E: } \\
\text { Garden with } \\
\text { horticultural } \\
\text { activates }\end{array}$ & & & $\begin{array}{l}\text { Hardscape: arrangement of the cluster of trees and tree as a } \\
\text { cornerstone or a reference point } \\
\text { Softscape: integration of trees and vegetable for production with } \\
\text { banana trees and avocado } \\
\text { Function: farm and garden } \\
\text { Activities: productive, private }\end{array}$ \\
\hline 6 & $\begin{array}{l}\text { F: } \\
\text { Garden with } \\
\text { farming } \\
\text { activates }\end{array}$ & & 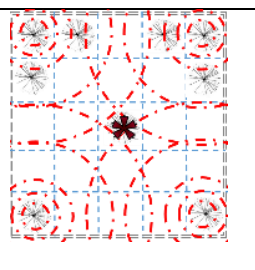 & $\begin{array}{l}\text { Hardscape: defined the boundary of the land using of the tress } \\
\text { with a central void, this format also creates an internal space for } \\
\text { other activities. } \\
\text { Softscape: a bunch of fruit and non-fruit trees in surrounding } \\
\text { with vegetable in between } \\
\text { Function: farm and garden } \\
\text { Activities: productive and private }\end{array}$ \\
\hline 7 & $\begin{array}{l}\text { G: } \\
\text { Flower } \\
\text { Garden with } \\
\text { ceremony } \\
\text { activity }\end{array}$ & 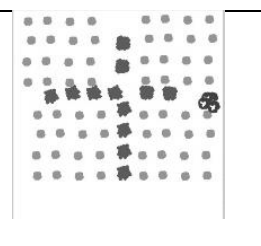 & $\begin{array}{ll}x \\
+\end{array}$ & $\begin{array}{l}\text { Hardscape: trees as hedges in the centre to define sub-space for } \\
\text { flowers planting } \\
\text { Softscape: fruit trees in the centre and the flowers gardens in the } \\
\text { surrounding } \\
\text { Function: flower garden } \\
\text { Activities: private and productive, and ceremony events }\end{array}$ \\
\hline 8 & $\begin{array}{l}\mathrm{H}: \\
\text { Garden with } \\
\text { building }\end{array}$ & 8***: & 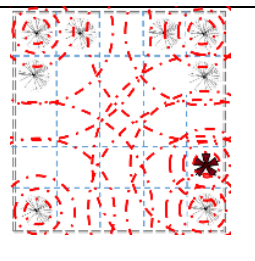 & $\begin{array}{l}\text { Hardscape: sample of a colonial villa house in the city, filling } \\
\text { the corners with natural elements and house as a reference point } \\
\text { with an open centre } \\
\text { Softscape: wood and decorative trees, flowers, and pots such as } \\
\text { Grevillea, Pine, and Shrubs } \\
\text { Function: housing } \\
\text { Activities: living area, private }\end{array}$ \\
\hline
\end{tabular}




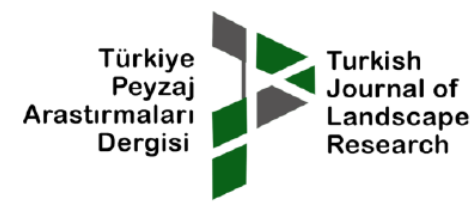

Table 4. Analytical table of the Transformed Gardens

\begin{tabular}{|c|c|c|c|c|}
\hline No & Location & $\begin{array}{l}\text { Layout of the } \\
\text { Gardens }\end{array}$ & $\begin{array}{l}\text { Graphical } \\
\text { Analysis of the } \\
\text { Structure }\end{array}$ & Explanation \\
\hline 1 & $\begin{array}{l}\text { I: } \\
\text { Garden as a } \\
\text { student's } \\
\text { centre }\end{array}$ & $\frac{1}{10}$ & 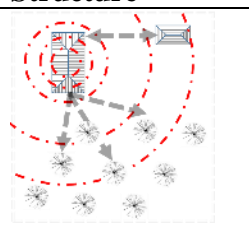 & $\begin{array}{l}\text { Hardscape: The building as the main element, the greenery as } \\
\text { the second layer of the garden, lawn, } \\
\text { Softscape: lawn and separated trees for more visibility } \\
\text { Function: office and students visiting } \\
\text { Activities: playground, community centre, interaction, short } \\
\text { course training, private }\end{array}$ \\
\hline 2 & $\begin{array}{l}\mathrm{J}: \\
\text { Garden and } \\
\text { Office }\end{array}$ & & 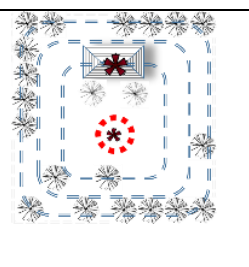 & $\begin{array}{l}\text { Hardscape: The building as main element and the linear planting } \\
\text { created boundary with open space in the middle } \\
\text { Softscape: wood trees in surrounding such as grevillea, } \\
\text { Jacaranda, and Bamboo, and fruit trees in middle such as } \\
\text { avocado, guava, and banana, also shrubs and flowers as edges } \\
\text { Function: office } \\
\text { Activities: private, business, }\end{array}$ \\
\hline 3 & $\begin{array}{l}\mathrm{K}: \\
\text { Garden as a } \\
\text { Wedding } \\
\text { Garden }\end{array}$ & & & $\begin{array}{l}\text { Hardscape: space and subspace in geometric form based on the } \\
\text { accessibility with a central void } \\
\text { Softscape: wood trees planted as reference points to address the } \\
\text { boundary of subspaces such as Grevillea, Pine, and Talisay and } \\
\text { shrubs as hedges to define subspaces } \\
\text { Function: Recreational and cultural } \\
\text { Activities: semi private-public, wedding garden, ceremony }\end{array}$ \\
\hline 4 & $\begin{array}{l}\text { L: } \\
\text { Garden as a } \\
\text { Resultant }\end{array}$ & $: 000$ & 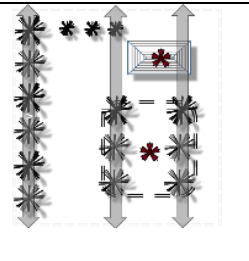 & $\begin{array}{l}\text { Hardscape: a parallel-linear structure with hangout spots as } \\
\text { subspaces in a clear geometric form } \\
\text { Softscape: The surrounding trees included barren species, } \\
\text { however, interior trees composed from fruitful such as mango, } \\
\text { avocado, and guava. } \\
\text { Function: restaurant } \\
\text { Activities: semi-private, leisure time, interaction }\end{array}$ \\
\hline 5 & $\begin{array}{l}\text { M: } \\
\text { Garden as a } \\
\text { leftover part } \\
\text { of land }\end{array}$ & & & $\begin{array}{l}\text { Hardscape: This structure is so defensive to protect the inside of } \\
\text { the garden as the central void. } \\
\text { Softscape: the garden included a densified façade with } \\
\text { decorative trees such as Jacaranda and Palm and lawn in center. } \\
\text { Function: garden, green space } \\
\text { Activities: private, reserved }\end{array}$ \\
\hline 6 & $\begin{array}{l}\mathrm{N}: \\
\text { Garden as a } \\
\text { Roundabout }\end{array}$ & & 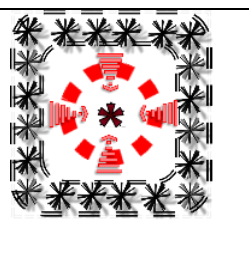 & $\begin{array}{l}\text { Hardscape: This structure also is another style of defensive form } \\
\text { of planting those trees. The surrounding area of the old } \\
\text { roundabout occupied. } \\
\text { Softscape: trees and inside row of palm trees with some } \\
\text { decorative flowers and seats } \\
\text { Function: roundabout } \\
\text { Activities: public service, traffic, accessibility }\end{array}$ \\
\hline 7 & $\begin{array}{l}\text { O: } \\
\text { Garden as an } \\
\text { office for } \\
\text { church }\end{array}$ & & 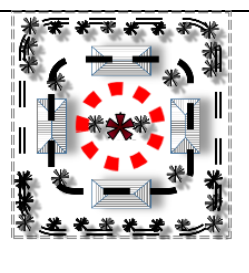 & $\begin{array}{l}\text { Hardscape: the central courtyard based on the arrangement of } \\
\text { houses and trees, subspaces in the surrounding, the central void } \\
\text { as a focal point. } \\
\text { Softscape: decorative trees and shrubs in a geometric and } \\
\text { symmetric form for more transparency and visibility } \\
\text { Function: church, office } \\
\text { Activities: semi-private, official activities }\end{array}$ \\
\hline 8 & $\begin{array}{l}\text { P: } \\
\text { Garden as a } \\
\text { wedding } \\
\text { garden }\end{array}$ & $\int_{0}^{6}$ & 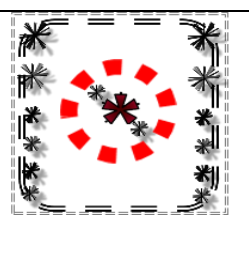 & $\begin{array}{l}\text { Hardscape: The natural grass as open space and subspaces, and } \\
\text { a linear structure with two functional parts with a central void } \\
\text { and surrounding boundary } \\
\text { Softscape: Grevillea, Talisay, and Pine as wood trees in the } \\
\text { surrounding and shrubs as edges } \\
\text { Function: Recreational and cultural } \\
\text { Activities: semi private-public, wedding garden, ceremony }\end{array}$ \\
\hline
\end{tabular}




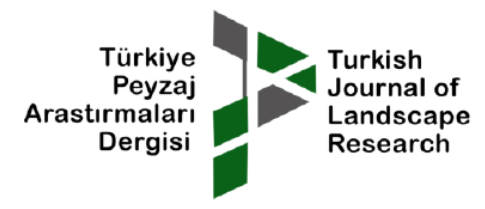

\subsection{Analysis of the Results}

Research Article

The form of the landscape of the city is going to change through the process of deforming the gardens. The functions of the gardens are varied from private-productive to semi-private-non-productive specifications. The traditional gardens are more productive and private with some specific purposes such as farm-garden, housegarden, and church-garden. However, the transformed gardens are more semi-private or semi-public, which are transferred for recreational activities such as restaurant and wedding garden, or official activities such as office, institution, and religious centre. Apparently, the transformed gardens prioritize public activities, which are open to the public than limited to the individual or a single family. In other words, the traditional gardens serve just a limited activity as production for the minimum number of users such as farmer and the family; however, in the transformed gardens the activities are varied based on the purpose of users including consumers, visitors, and owner. The new group of the garden facilitate activities of users to spend their times in the gardens based on the different schedules, payment for activities, and an administrative process for services. Therefore, in the transformed gardens the function of the garden could serve more wide range of the inhabitants than a traditional garden. The payment of the attendees reveals to the specific social class of the users who are ready to pay for leisure times the transformed gardens. Therefore, the new form of the landscape is more penetrated physically by the users than traditional gardens.

According to the results, the general form of the gardens is included a trend toward the geometric or semigeometric shapes in both traditional and transformed gardens based on two elements including the natural contour lines and the traces of water runoff (Tables 3 and 4). In fact, both upper and lower contour lines formed a sample way to subdivide the land based on the topography without terracing. These two elements construct the general form of the landscape in the city and surrounding areas with check-square shapes. In this regard, the boundaries of gardens are determined with two different trends based on the function and activities inside the gardens. For the productive gardens, the boundary of the land is highlighted by some separated elements such as trees, shrubs, or other natural elements due to the visibility and lighting in the gardens. Seemingly, the trees as a boundary include the character as a reference point. Despite the traditional gardens are open for the visual penetration of the passerby, the transformed gardens are surrounded by walls, fences, and multilayers of trees as physical elements to reduce the possibility of the observability, visibility, and monitoring the garden from outside for the more specific activities such as restaurant, wedding garden, and or institutional activities in Table 4. Therefore, the new form of landscape with both hardscape and softscape hedges appear in the city to protect the restaurants, offices, and wedding gardens from outside visibility.

In addition, the hardscape of gardens is followed by the main function of the gardens. In fact, the gardens with a productive function just include land and area with some trees and vegetables as productive goods, which are no or less included any decorative elements of infrastructure. However, the transitional gardens are more semi-public, in which the owner invest budget for the improvement of both hardscape and softscape to attract users to attend in the garden. For this reason, the materials and species include a variety in transformed gardens such as pavement, paths, decorative flowers, colourful hardscape and softscape, flowerboxes, pots and vases, and furniture. Apparently, new groups of owners and users pay more attention to the beatification, aesthetic, enjoyment, and attraction of the new generation of gardens than productive.

The softscape in both gardens includes varieties of green spaces. The traditional gardens encompass both forest and fruitful trees, however, a bunch of trees are the common characteristic of those gardens such as banana and avocado trees. The forest trees normally take the position in the surrounding areas of the gardens as a reference point of the land. Vegetation covers the whole part of the land commonly beans, maize, flower, and vegetables. While, in the transformed gardens, some decorative elements are added to the softscape to make variety such as decorative trees, flowers, and shrubs, also some hardscape such as walls, gates, paving, sitting areas. Metal fences and walls are new materials to define transformed gardens those normally cover with vines such as Ficus Pumila, Bougainvillea, and Trumpet Vine. Despite the increase of the decorative elements in the softscape, the fruit trees conserve in the location as one of the main element in the softscape structure in the transitional gardens although vegetation is converted to the flowers. It is significant to highlight that the trend to add decorative elements to the gardens reveals the interests of new users and owners to spend money on the softscape for leisure activity as a new social class.

Additionally, the shape of the central void in both gardens is a permanent concept, which is appeared with a different form and character. In fact, in the transformed garden, this void focuses the main activity in the central 


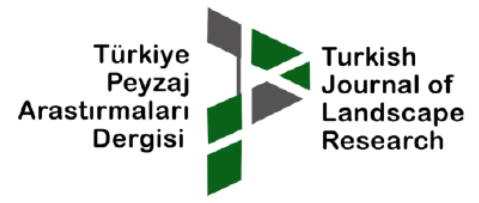

part as the main character of the areas. Therefore, transparency, visibility, and permeability are three functional aspects of the voids in the transformed gardens. The void also should be accessible and observable by the users as the most important part of the area to create a sense of exploration and curiosity in users. However, in the traditional gardens, the central void encompasses the function as the reference point to arrange the productive activities in the other parts as the cornerstone.

\subsection{Discussion}

Studies on the garden identified that the concepts of spiritual (Pregill \& Volkman, 1999; Eyres, 2013), ritual (Gleason, 2010; Wilkinson, 1994), and leisure activities (Huang, Tuan, \& Wongchai, 2014) contrasted with the meaning of the traditional garden in the area. The traditional gardens have been in line with Micoulina theory, as the agricultural plot with manmade efforts (Micoulina, 2010). Therefore, traditional gardens were full of edibles species like fruits and vegetables than decorative. Hence, the theory of Owusu based on the distortion of agriculture and horticulture (Owusu, 1993) was not achievable in the study. Additionally, the theory of the natural pattern of gardens in the context of Affric had a little bit of deviation based on the Gokyer idea (Gökyer, 2013). In detail, the naturalistic form of gardens in the context was more dependent on the softscape than the hardscape. Indeed, the form of the land conserved particularly in the case of the topography and form of plots, but the coverage changed based on the current tendency similar to the results of Shin and Goldsmith (Goldsmith, 2014; Shin, Chen, Lee, \& Kim, 2015).

The results of studies demonstrated that the function of those transformed gardens majority adapted to the recreational and semi-private-public activities; those were tended to increase the advantage from both land and green spaces based on the new functions and activities. This result was so similar to Hermand theory as the effects of middle-class enhancement and enlightenment movement in the changing of gardens (Hermand, 1997). This new class also as the resident, owner, and stakeholder changed the form of the garden due to the hardscape and softscape to form new composition and configuration based on their want, desire, and new cultural aspects that were so close to the ad hoc and eclectic theory were discussed by (Tafahomi \& Nadi, 2020; Tafahomi, 2021). The intervention was included two parts containing the softscape part with adding decorative elements, trees, and flowers, also the hardscape part with adding walls, furniture, gates, and particularly roads as the right to accessibility. This observation was similar to the findings of Fu and Ruggeri as the changing of the urban green spaces by stakeholders results of Bigell and Chang as the cultural influences for changing of the gardens (Fu, Xiao, \& Wu, 2016; Bigell \& Chang, 2014). Furthermore, the results confirmed the outcomes of the study of Paganova and Jurekova to change trees in the softscape by users, and Baard and Kraaij on the effective factors of changing both hardscape and softscape of landscape (Ruggeri, Mazzocchi, \& Corsi, 2016; Paganová \& Jureková, 2012; Baard \& Kraaij, 2014).

For this reason, also those transformed gardens have been more geometric to present a new aspect of the public activities and behavioural patterns as a cultural and historical transformation. The level of transparency in terms of permeability and accessibility increased the variety of users, and the public found the right to attend in the spaces in the major part of the transformed gardens. Therefore, this result diverged from arguments of both Owusu and Mazrui as the negative effects of modernisation (Owusu, 1993; Mazrui, 1993). In fact, stakeholders conserved the green spaces and then added decorative species to adapt the gardens to semi-publicprivate activities than private productions. Therefore, the new form and function of those transformed gardens could more support the social and public activities as the symbol of urbanisation, analogous with results of Swaffield as the own designing of the personal form of the garden and Antrop by means of the urbanisation and modernisation process of the landscape (Swaffield \& Primdahl, 2006; Antrop \& Eetvelde, 2008; Antrop M. , 2013).

According to the analysis and findings, the amazing aspects of the research was to discover the void in the central part of the gardens, as a symbolic meaning of the arranging, planning, and designing of gardens. In fact, the central void in the traditional garden highlighted a symbolic space in the central part as the reference point including activities such as production or connection such as ownership and gathering activities. This character by means of referring to the location was similar to studies of Bigell, Chang, and Micoulina as the cultural effects on the landscape; however, the findings did not reach any aspect of the spiritual or recreational aspect similar to Cannon and Kua (Bigell \& Chang, 2014; Cannon \& Kua, 2017; Micoulina, 2010). Additionally, the central void redesigned based on the recreational activities, visibility, and transparency in the transformed gardens than the ownership aspect. This specification could demonstrate the rising of a new 


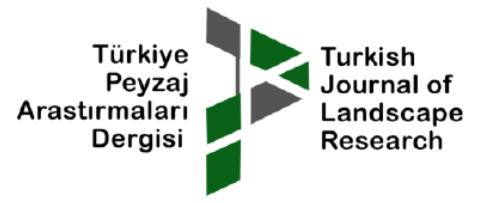

middle social class with recreational and leisure tendency (Gökyer, 2013) in the semi-public spaces due to the cultural and historical movement (Shin, Chen, Lee, \& Kim, 2015) and hinterland specifications (Crowder, 1993) in the city.

\section{CONCLUSION}

The transition process of gardens in the city has been a continuous trend with diverse specifications particularly from forest to agroforestry and farms. Importantly, the current process of change has been more a procedure of integration, adaptation, and accessibility due to the public need than transformation. Indeed, this process has tended to renovate the gardens from the product types such as farm, agroforestry, agricultural plot into recreational trends such as the restaurants, wedding gardens, and intuitional offices for social interaction.

The current study finds that transformed gardens tend to be more semi-private and semi-public than traditional gardens as private. The main objective of the transformed gardens changed from production to leisure activities, so, the accessibility of other people facilitated these gardens particularly those who could afford the payment for leisure. In fact, leisure and recreational activities are important functions in the transformed gardens. For this reason, all transformed samples encompass a geometric accessibility network to facilitate walking, stopping, watching, and leisure activities. This specification of the transformed gardens makes the gate open to the public at certain times. However, in those traditional gardens, a single-family or group of families use the land to produce vegetation and fruits for the self-consumption or market.

The process of transformation also refers to the social classification of the city. Indeed, the city has confronted with investment, service jobs, and international centres, so this integration of the country in the global economy has created a new middle-class of inhabitants with the urban level of need, desire, and expectation from landscape design. Therefore, the former structure based on self-productive and self-consumption can no longer answer to the need for these new groups of users in the absence of recreational facilities, functions, activities, and centres. Besides, the process of changing the functions and activities in the gardens result in changing the accessibility, permeability, and legibility of those gardens from private, limited, microscale to the semi-public, open, and macro-scale in the city.

The landscape of the area faces a new configuration in the gardens based on the application of new materials and constructions to determine the territory of the gardens by the physical elements and manmade symbols. The form of the new gardens improves based on the inside visibility, transparency, and legibility. It means the transformed gardens reduce the density of green spaces with a paving network to fill the space with more users. Inevitably, this action results in increasing hardscape with more openness as an important factor of permeability. Furthermore, the central void has been kept in all precedents with varieties of openness without any contradiction with the new functions of the gardens.

This transformation not only enhances the decorative aspect of gardens with adding flowers, pots, and seats and benches for sitting but also, with conserving most parts of fruit trees and adding some ornamental species to the composition, the owners innovate a new softscape that could be called as an eclectic form in the context. In this regard, analogous trees are observed in both kinds of gardens such as forest trees like Grevillea, Pines, and Palm, or fruit trees like Banana, Avocado, guava, and Mango. In addition, other trees such as Jacaranda, Acacia, and Talisay trees also are added to the structure. Decorative pots, flowers, and shrubs as hedges apply in this new composition. These simple elements change the atmosphere of the landscape from productive gardens into a new generation of semi-open and semi-public gardens in the urban areas. This specification changes the character of reference pointing of the gardens from a micro-scale in the just portion of the city into functionality in a macro-scale in the whole scale of the city. Although the traditional gardens have more connection with the suburb configuration and composition as an agricultural function, the transformed gardens play the role in the urban level with the new generation of the landscape, hardscape, softscape, and public activities.

\section{Acknowledgement}

This research would like to appreciate all participants particularly the fourth year students in the department of architecture in 2018 and the owner of the gardens those who cooperated with the research in the collecting of data. 


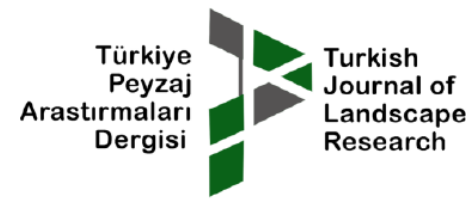

\section{REFERENCES}

Alexsander, C. (1977). A pattern language. New York: Oxford University Press.

Antrop, M. (2013). A brief history of landscape research. In P. Howard, I. Thompson, \& E. Waterton, The Routledge Companion to Landscape Studies (pp. 12-22). New York: The Routledge.

Antrop, M., \& Eetvelde, V. V. (2008). Mechanisms in recent landscape transformation. (Ü. B.-D. Mander, Ed.) Geo-Environment and Landscape Evolution III, 183-192.

APA, A. (2006). Planning and urban design standards. New Jersey: John Wiley and Sons Inc.

Baard, J. A., \& Kraaij, T. (2014). Alien flora of the Garden Route National Park, South Africa. Alien flora of the Garden Route National Park, South Africa, 94, 51-63.

Backeus, I., Lindberg, C., \& Stromquist, L. (2009). Past, present, and future: Perspectives in landscape dynamics as seen from two case studies in Tanzania. In E. Kalipeni, I. Kakoma, Y. Sanogo, K. Fawcett, \& R. Warner (Eds.), Turning science into action: Biodiversity conservation and natural resources management In Africa (pp. 157-169). Kigali, Rwanda: Africa World Press Inc.

Bairnsfather, N. (2012). Remarkable gardens of South Africa. Cape Town: Quiver tree Publications.

Bashir, A. (2007). A case for historical and landscape approaches to geography. Journal of the Environment, 2, 53-62.

Bell, S. (2004). Elements of visual design in the landscape (Second ed.). New York: Spon.

Bell, S. (2008). Design for outdoor recreation (Second ed.). London: Taylor \& Francis.

Bigell, W., \& Chang, C. (2014). The meanings of landscape: Historical development, cultural frames, linguistic variation, and antonyms. Ecozon, 5(1), 84-103.

Bonnes, M., \& Bonaiuto, M. (2002). Environmental psychology: From spatial-physical environment to sustainable development. In R. B. Bechtel, \& A. Churchman (Eds.), Handbook of environmental psychology (pp. 28-54). New York: John Wiley \& Sons, Inc.

Bowring, J. (2014). On loanwords and calques: the appropriation and replication of geomorphological features in gardens. Hamilton Gardens (p. N/A). Hamilton, New Zealand: Hamilton Gardens.

Buyinza, M. (2004). Forestry education in changing landscape: Emerging lessons from Uganda. Makerere Journal of Education, 1, 61-68.

Cannon, C. H., \& Kua, C. S. (2017). Botanic gardens should lead the way to create a "Garden Earth" in the Anthropocene. Plant Diversity, 1-7.

CoK. (2013). Detailed district physical plan. Kigali: City of Kigali.

CoK. (2015). Affordable housing for Kigali city. Kigali: Cok.

Crowder, M. (1993). Africa under British and Belgian domination, 1935-45. In A. A. Mazuri, \& C. Cwondji, General history of Africa, VIII, Africa since 1935 (pp. 76-104). Paris: UNESCO.

Deming, E. M., \& Swaffield, S. (2011). Landscape architecture research: Inquiry, strategy, design. New Jersey: John Wiley \& Sons, Inc.

Denzin, N. K., \& Lincoln, Y. S. (2018). The SAGE handbook of qualitative research (5 ed.). Los Angeles: SAGE Publications, Inc.

Duflot, R., Ernoult, A., Aviron, S., Fahrig, L., \& Burel, F. (2017). Relative effects of landscape composition and configuration on multi-habitat gamma diversity in agricultural landscapes. Agriculture, Ecosystems and Environment, 241, 62-69.

Eyres, P. (2013). A cultural history of gardens in the age of enlightenment. London: Bloomsbury.

Fu, J., Xiao, G., \& Wu, C. (2016). Urban green transition: conceptual change and stakeholder involvement in depth. Urban Transitions Conference. 198, pp. 781 - 789. Shanghai: Procedia Engineering.

Georgoula, O., Stamnas, A., Patias, P., Georgiadis, C., \& Fragkoulidou, V. (2013). Historical coastal urban landscapes digital documentation and temporal study with 2D/3D modeling functionality: The case of Thessaloniki, Greece. Journal of Cultural Heritage, 14(5), 396-402.

Given, L. M. (2008). The SAGE encyclopedia of qualitative research methods (Vols. 1-0). Thousand Oaks, CA: SAGE Publications, Inc. doi:10.4135/9781412963909

Gleason, K. (2010). Constructing nature: The built garden, with notice of a new monumental garden at the Villa Arianna, Stabiae. International Congress of Classical Archaeology. D / D9 /3, pp. 8-15. Rome: Bollettino di Archeologia.

Gökyer, E. (2013). Understanding landscape structure using Landscape metrics. Advances in Landscape Architecture, 663-676. Retrieved from http://dx.doi.org/10.5772/55758 


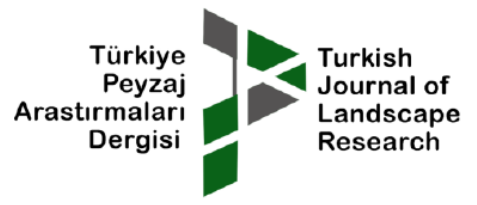

Goldsmith, S. (2014). Turning over old ground: an examination of garden heritage in Aotearoa New Zealand.

Garden at the frontier: New perspective on gardens history. Hamilton: Hamilton Gardens.

Groat, L., \& Wang, D. (2002). Architectural research methods. New York: John Wiley \& Sons INC.

Groening, G. (2005). Aspects of garden culture and open space development in Germany. GEOUSP - Espaço e Teтpo, 18, $201-212$.

Groening, G. (2007). The "landscape must become the law" - or should it? Landscape Research, 32(5), 595612.

Groening, G., \& Hennecke, S. (2014). Urban greening: Macro-scale landscaping. Horticulture: Plants for People and Places, 2, 671-692.

Groening, G., \& Schneider, U. (1997). The urban private garden as an amplification of the house: leisure according to regulation. Nordisk Arkitektur Forskning, 1, 21-30.

Groning, G., \& Wolschke-Bulmahn, J. (2003). The native plant enthusiasm. Landscape Research, 28(1).

Hall, M. (2003). The native, naturalized and exotic, plants and animals in human history. Landscape Research, 28(1), 5-9.

Harris, C. W., \& Dines, N. T. (1998). Time saver standard for landscape architecture: Design and construction data (2nd ed.). New York: McGraw-Hill Publishing Company.

Helmreich, A. (2002). The English garden and national identity, the competing styles of garden design 18701914. Cambridge: Cambridge University Press.

Hermand, J. (1997). Rousseau, Goethe, Humboldt: Their influence on later advocates of the nature garden. In J. Wolschke-Bulmahn, Nature and ideology, natural garden design in the twentieth century (pp. 3557). Washington, D.C.: Dumbarton Oaks Research Library and Collection.

Hopper, L. J. (2007). Landscape architecture graphic standards. New Jersey: John Wily \& Sons.

Huang, C. M., Tuan, C. L., \& Wongchai, A. (2014). Development analysis of leisure agriculture: A case study of longjing tea garden, Hangzhou, China. APCBEE Procedia 8 (pp. 210 - 215). ScienceDirect.

Jackson, B. J. (1979). The order of a landscape: Reason and religion in Newtonian America, the interpretation of ordinary landscapes. In D. W. Meinig, Geographical Essays (pp. 153-163). New York: Oxford University Press.

Keswick, M., Hardie, A., \& Jencks, C. (2003). The Chinese garden: History, art and architecture (3 edition ed.). New York: Harvard University Press.

Khansari, M., Moghtader, M. R., \& Yavari, M. (2003). The Persian garden: Echoes of paradise. Toronto: Mage Publishers.

Koskinen, I., Zimmerman, J., Binder, T., Redstrom, J., \& Wensveen, S. (2011). Design Research through Practice. New York: Elsevier, Morgan Kaufmann.

Krippendorff, K. H. (2003). Content analysis: An introduction to its methodology (2nd edition ed.). New York: Sage Publications.

Laseau, P. (2000). Graphic thinking for architects and designers (3th ed.). New York: Wiley.

Marshall, C., \& Rossman, G. B. (2006). Designing qualitative research. New York: SAGE Publications.

Mazrui, A. A. (1993). Towards the year 2000. In A. A. Mazrui, \& C. Wondji, General History of Africa VIII, Africa since 1935 (pp. 905-933). Paris: UNESCO.

Micoulina, E. (2010). The history of gardens and the evolution of the environment. Retrieved from https://www.icomos.org/publications/93garden7.pdf

Milam, J. (2017). Cosmopolitan translation and patriotic sensibilities in German garden art. Intellectual History Review: Visual and Aural Intellectual Histories, 27(3), 377-403.

Miller, G., Dingwall, R., \& Morphy, E. (2004). Using qualitative data and analysis. In D. Silverman, Qualitative research: Theory, method, and practice (pp. 325-341). London: Sage Publications.

MININFRA. (2015). Rwanda report Habitat III. Kigali: Rwanda Ministry of Infrastructure.

Morris, A. E. (1979). History of the urban form. London: George Godwin Limited.

Moughtin, C., \& Shirley, P. (2006). Urban design: Green dimensions (2 ed.). Oxford: Architectural Press.

Mugerauer, R. (1995). Interpreting environments: tradition, deconstruction, hermeneutics. Texas: University of Texas.

Mugerauer, R. (2014). Interpreting nature: the emerging field of environmental hermeneutics. Robert: Fordham University Press.

Munyaneza, E., Bizuro, E., Nshutiyayesu, S., Bigendako, M. J., \& Minani, V. (2009). The role of cultural practices in the conservation of biodiversity in Rwanda. In E. Kalipeni, I. Kakoma, Y. Sanogo, K. 


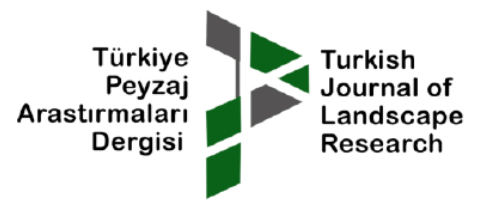

Fawcett, \& R. Warner (Eds.), Turning science into action: Biodiversity conservation and natural resources management In Africa (pp. 417-430). Kigali, Rwanda: Africa World Press Inc.

Neuman, W. L. (2006). Social research methods: Qualitative and quantitative approaches. London: Pearson Education, Ink, Fifth Edition.

Newbury, D. (1992). Kings and clans, Ijwi Island and the Lake Kivu Rift, 1780-1840. Wisconsin: The University of Wisconsin Press.

Niezabitowska, E. D. (2018). Research methods and techniques in architecture (1st Edition ed.). New York: Routledger.

Noordwijk, M. v., Bizard, V., Wangpakapattanawong, P., Tata, H. L., Villamor, G. B., \& Leimona, B. (2014). Tree cover transitions and food security in Southeast Asia. Global Food Security, 3, 200-208.

O’Donoghue, R., Sandoval-Rivera, J. A., \& Payyappallimana, U. (2019). Landscape, memory and learning to change in changing worlds: Contemplating intergenerational learning and traditional knowledge practices within social-ecological landscapes of change. Southern African Journal of Environmental Education, 35, 1-34.

Owusu, M. (1993). Agriculture and rural development since 1935. In A. A. Mazuri, \& C. Wondji, General history of Africa, VIII, Africa since 1935 (pp. 317-356). Paris: Heinemann, UNESCO.

OZ, A. (2007). Conceptual master plan of Kigali city. Kigali: City of Kigali.

Paganová, V., \& Jureková, Z. (2012). Woody plants in landscape planning and landscape design. (M. Ozyavuz, Ed.) Landscape Planning, 199-216. Retrieved from http://www.intechopen.com/books/landscapeplanning/woody-plants-in-landscape-planning-and-landscape design

Pregill, P., \& Volkman, N. (1999). Landscapes in history: Design and planning in the Eastern and Western traditions (Second ed.). New York: John Wiley.

Regis, R. (2003). Sketchbook: Piazza di Spagna, Rome. In D. Watson, A. Plattus, \& R. Shibley, Time saver standards for urban design (pp. 441-448). New York: Mc Grow Hill.

REMA, R. (2017). Rwanda: State of environment and outlook report 2017. Kigali: REMA.

Robinson, N. (2004). The planting design handbook (Second Edition ed.). Hants, England: Ashgate Publishing Limited.

Ruggeri, G., Mazzocchi, C., \& Corsi, S. (2016). Urban gardeners' motivations in a Metropolitan city: The case of Milan. Sustainability, 8, 1-19.

Sampson, R., \& Gifford, S. M. (2010). Place-making, settlement and well-being: The therapeutic landscapes of ecently arrived youth with refugee backgrounds. Health \& Place, 16, 116-131.

Schenker, H. (2013). A cultural history of gardens in the age of the empire. (S. Dümpelmann, Ed.) London: Bloomsbury.

Shin, H. S., Chen, Y., Lee, W. H., \& Kim, H. D. (2015). Sustainability of historical landscape to Gwanghalluwon garden in Namwon city, Korea. Sustainability, 7, 8565-8586.

Silverman, D. (2004). Qualitative research: Theory, method and practice. New York: SAGE Publications Ltd.

Silverman, D. (2010). Doing qualitative research. New York: SAGE Publisher.

Sperlregen, P. D. (2003). Making as visual survey. In D. Watson, A. Plattus, \& R. Shibley, Time saver standards for urban design (pp. 431-440). New York: Mc Grow Hill.

Spirn, A. W. (1998). The language of landscape. New Haven: Yale University Press.

Steckel, J., Westphal, C., Peters, M. K., Bellach, M., Rothenwoehrer, C., Erasmi, S., . . Steffan-Dewenter, I. (2014). Landscape composition and configuration differently affect trap-nesting bees, wasps and their antagonists. Biological Conservation, 172, 56-64.

Swaffield, S., \& Primdahl, J. (2006). Spatial concepts in landscape analysis and policy: some implications of globalisation. Landscape Ecology, 21(3), 315-331.

Tafahomi, R. (2021). Application of physical and nonphysical elements in the conservation of historic core of city. South African Journal of Geomatics, 10(1), 75-86. doi:10.4314/sajg.v10i1.6

Tafahomi, R. (2021). Qualities of the green landscape in primary schools, deficiencies and opportunities for health of the pupils. J. Fundam. Appl . Sci, 13(2), 1093 -1116. doi:10.43 14/jfas.v13i2.25

Tafahomi, R., \& Nadi, R. (2016). Dehistoricisation the urban landscape through transition of the enclosure ratio in urban fabric of Gonabad city in Iran. $J$ Archit Eng Tech, Volume 5(Issue 2). doi:doi:10.4172/2168-9717.1000162 


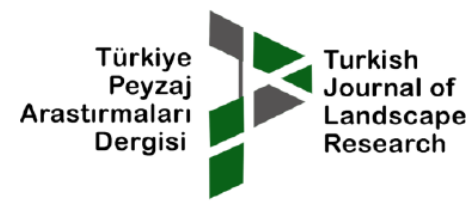

Tafahomi, R., \& Nadi, R. (2020). Derivation of a design solution for the conservation of a historical Payab in the redevelopment of Doloeei, Gonabad. International Journal of Built Environment and Sustainability, 7(1), 1-9. doi:10.11113/ijbes.v7.n1.407

Tafahomi, R., \& Nadi, R. (2020). Insight into the missing aspects of therapeutic landscape in psychological centers in Kigali, Rwanda. Cities \& Health, 1-13. doi:10.1080/23748834.2020.1774035

Tessin, W. (1994). Der traum vom garten - ein planerischer alptraum. Berline, Germany: Peter Lang AG.

Trancik, R. (1986). Finding lost space, theories of urban design. New York: Wiley.

Turner, M. G. (2015). Spatial statistics. In M. G. Turner, \& R. H. Gardner, Landscape ecology in theory and practice (pp. 143-174). New York: Springer.

Turner, M. G., \& Gardner, R. H. (1994). Quantitative methods in landscape ecology. London: Springer .

Westmacott, R. (1992). African-American gardens: Yards in rural South. New York: University Tennessee Press.

White, E. T. (1983). Site analysis: Diagramming information for architectural design. Tallahassee, Florida: Architectural Media Ltd.

Wilkinson, A. (1994). Symbolism and design in ancient Egyptian gardens. Garden History, 22(1), 1-17. Retrieved from http://www.jstor.org/stable/1586999

Wolschke-Bulmahn, J., \& Groening, G. (1992). The ideology of the nature garden. Nationalistic trends in garden design in Germany during the early twentieth century. the Journal of Garden History, 12(1), 73-80.

World Bank. (2012). Informal housing: reducing disaster vulnerability through safer construction. Kigali, Rwanda : World Bank.

Young, D., Young, M., \& Yew, T. H. (2011). The art of the Japanese garden. Toronto: Tuttle Publishing. 